\title{
INTRADERMAL B.C.G. VACCINATION BY DERMO-JET
}

\author{
Lieutenant-Colonel J. G. P. POWER, \\ M.B., B.Ch., D.P.H., D.T.M.\&H., D.I.H., R.A.M.C. \\ Deputy Assistant Director of Army Health, Rhine Area, B.A.O.R.
}

A METHOD of rapid, painless, automatic, and effective intradermal B.C.G. vaccination using a straight type of Dermo-jet injector was described by Griffiths et al (1965). A similar instrument has been used successfully to administer measles vaccine (Bleasdale 1965, Cooper et al 1966).

A small-scale trial of the Dermo-jet as compared with the usual intradermal needle and syringe method was carried out recently in school-children in B.A.O.R. An improved version of the Dermo-jet with an angled-head was used.

\section{Materials and Method}

Schoolchildren who were negative to the standard Heaf test using PPD containing 100,000 T.U. $/ \mathrm{ml}$. were vaccinated either by the intradermal injection of $0.1 \mathrm{ml}$. of freeze-dried B.C.G. vaccine (Glaxo) or by one shot of the same batch of vaccine administered by Dermo-jet.

Mantoux tuberculin-testing, using 10 T.U.PPD was carried out 8 ,weeks later and the results were read after 72 to 96 hours. The size of tuberculin reaction was measured by taking the mean of two diameters of induration. The size and type of local vaccination lesion was recorded at the same time. The recorder was unaware of the method of vaccination which had been used.

Figure 1 demonstrates the Dermo-jet being used to vaccinate a schoolgirl, and Figure 2 shows the essential working parts of the instrument.

\section{Results}

The results of tuberculin-testing and size of local B.C.G. vaccination lesions are shown in Tables I and II respectively.

The schoolchildren who took part in the trial were aged 11 to 19 years. Because of the necessarily long time interval between Heaf testing, BCG vaccination and the

Table 1

Results of Tuberculin-testing with 10 T.U. of PPD.

\begin{tabular}{|c|c|c|c|c|c|c|}
\hline & \multicolumn{6}{|c|}{ Results of Mantoux 10 T.U. } \\
\hline \multirow{2}{*}{$\begin{array}{c}\text { Batch } \\
\text { Number }\end{array}$} & \multicolumn{3}{|c|}{ Intradermal } & \multicolumn{3}{|c|}{ Jet Injector } \\
\hline & $\begin{array}{l}\text { Number } \\
\text { of } \\
\text { Children }\end{array}$ & $\begin{array}{l}\text { Per cent } \\
\text { Positive }\end{array}$ & $\begin{array}{c}\text { Mean } \\
\text { Induration } \\
(\mathrm{mm} .)\end{array}$ & $\begin{array}{c}\text { Number } \\
\text { of } \\
\text { Children }\end{array}$ & $\begin{array}{l}\text { Per cent } \\
\text { Positive }\end{array}$ & $\begin{array}{c}\text { Mean } \\
\text { Induration } \\
\text { (mm.) }\end{array}$ \\
\hline $2 / 66$ & 97 & 97.9 & 13.9 & 166 & 96.4 & 13,3 \\
\hline
\end{tabular}

*Now Deputy Assistant Director of Army Health, Land Forces, Hong Kong. 
Table 2

Local Reaction to Vaccination.

\begin{tabular}{c|c|c|c|c}
\hline \multirow{2}{*}{$\begin{array}{c}\text { Batch } \\
\text { Number }\end{array}$} & \multicolumn{3}{|c}{ Size of Vaccination Lesion } \\
\cline { 2 - 4 } & \multicolumn{2}{|c|}{ Intradermal } & \multicolumn{2}{c}{ Jet Injector } \\
\cline { 2 - 5 } & $\begin{array}{c}\text { Number } \\
\text { of } \\
\text { Children }\end{array}$ & $\begin{array}{c}\text { Mean } \\
\text { Size } \\
(\mathrm{mm} .)\end{array}$ & $\begin{array}{c}\text { Number } \\
\text { of } \\
\text { Children }\end{array}$ & $\begin{array}{c}\text { Mean } \\
\text { Size } \\
\text { (mm.) }\end{array}$ \\
\hline $\begin{array}{c}\text { Glaxo } \\
740 \mathrm{C}\end{array}$ & 97 & 6.5 & 165 & 7.1 \\
\hline
\end{tabular}

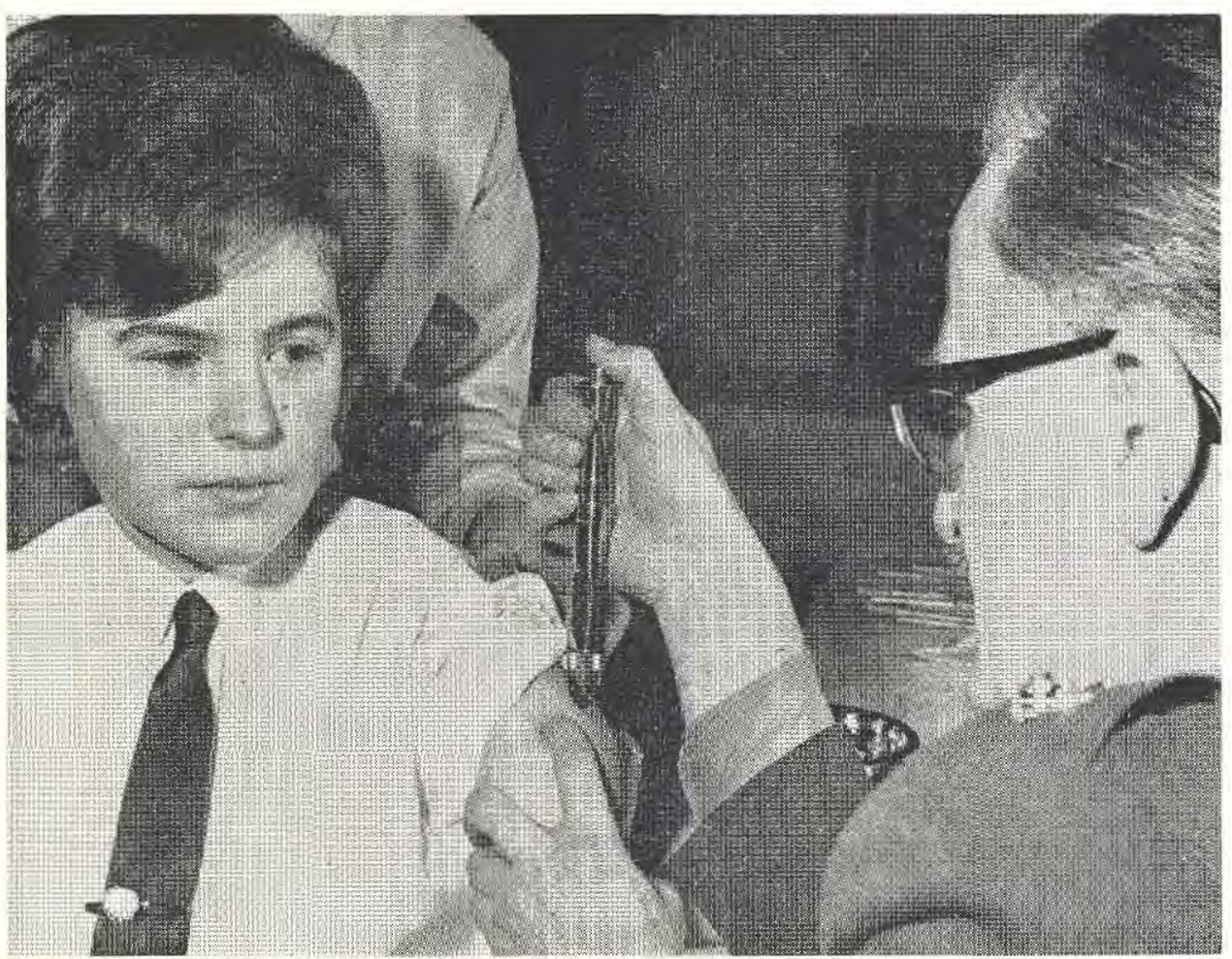

Fig. 1

final Mantoux conversion tests, only 263 of the original panel of 591 Heaf negative reactors completed the trial. The greatest wastage occurred between the completion of Heaf-testing and the setling-up, several months later, of the trial proper. During this time 272 children were struck off consequent on leaving school, illness etc. The excess numbers of children vaccinated by Dermo-jet as compared with the intradermal method occurred because of greater numbers of absentees in the latter group. This occurred by chance but in any case the total numbers are too small for any real significance to be attached to results. However they do at least support the findings of previous investigators and should provide a stimulus to future research. 
SCHUCO INTERNATIONAL LONDON LTD.

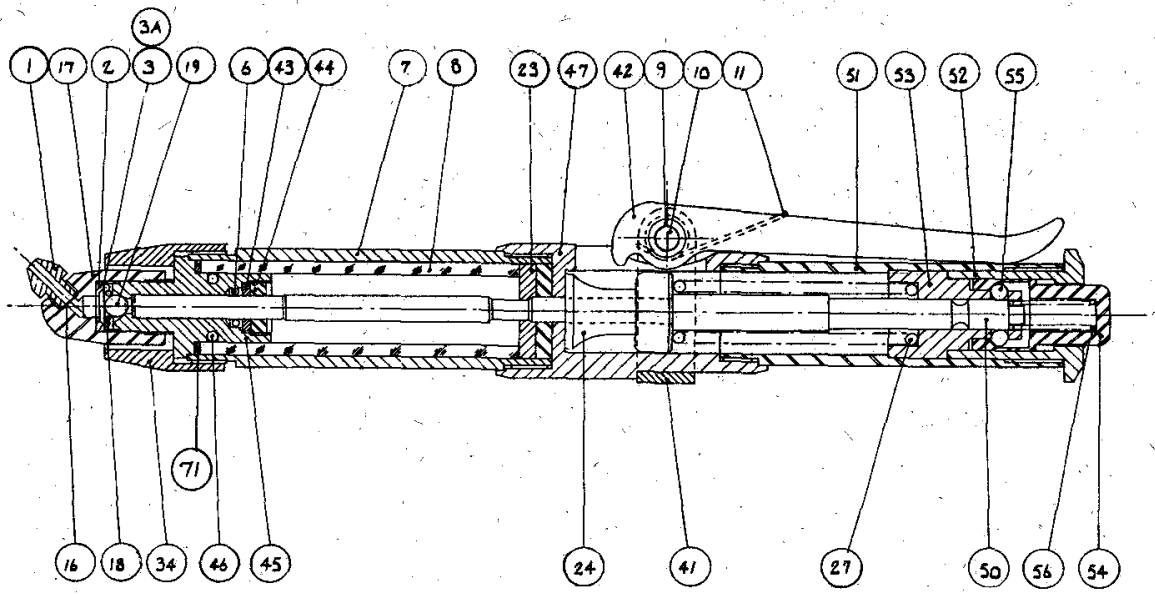

DERMO-JET MK.5.
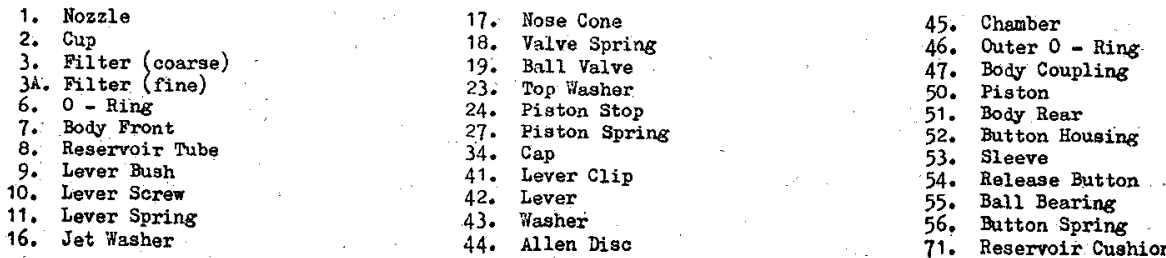

Fig. 2

The size of induration of the 10 T.U. Mantoux tests proved equally good in those vaccinated by Dermo-jet as by the intradermal method. The size of B.C.G. lesions appeared to be greater in those vaccinated by Dermo-jet. Conversely the degree of severity of local reaction, as measured by the amount of scar tissue, pigmentation, scaling and serous discharge in some cases, was greater in the intradermal group. The 10 T.U. PPD conversion rates were slightly higher in the latter group.

\section{Correct Dosage}

\section{Techniques}

Previous investigators estimated that the Dermo-jet delivered a single dose averaging 0.06 to $0.08 \mathrm{ml}$. The instrument used in this trial was found to deliver an average dose of $0.08 \mathrm{ml}$., provided sufficient vaccine was reconstituted with $5 \mathrm{ml}$. of sterile water, and exactly 50 shots were produced by loading the instrument in this manner.

\section{Depth of Penetration}

Weals consistent in size and appearance were produced in the children vaccinated by Dermo-jet but the blisters appeared to be more superficial than those achieved by intradermal injection. The depth of penetration was affected by skin texture and thickness and by subcutaneous fat. Oozing back of fluid from blisters was observed fairly fre- 
quently, and this necessitated cleansing of the recessed angled-nozzle of the Dermo-jet with sterile swabs. Visible bleeding did not occur and no vaccine was delivered subcutaneously in any of the children.

\section{Mechanical Faults}

Reloading the Dermo-jet after each shot was difficult due to stiffness of the cocking lever, and hand fatigue ensued in a short time. Lubrication of the mechanism in accordance with the manufacturer's instructions eased the lever but did not eliminate hand fatigue altogether. Near the end of the trial it was found that the weals suddenly had become much smaller and in a few cases no blister was formed. This was caused by partial blockage of the jet orifice by small fragments of disintegrated rubber from the black rubber ' $O$ ' ring component in the valve sleeve. These children were excluded from the trial.

\section{Adverse Reactions}

Only two cases of persistent discharge and delayed healing of the vaccination lesions were noted. Both of these were caused by unduly occlusive and restrictive dressings which caused irritation and proliferation of granulation tissue. They cleared up rapidly with treatment.

\section{Discussion}

The results of this small trial are in agreement with those of previous investigators (Griffiths et al 1965). As a painless and rapid method of effectively vaccinating large groups of school children the Dermo-jet has a marked advantage over the intradermal needle.

The disadvantages are failures due to mechanical faults, difficulty in achieving accurate dosage, and infection risks including passive transfer of serum hepatitis. In this trial only the mechanical faults described above were experienced. The makers now claim to have produced a better model of the Dermo-jet in which these faults have been eliminated and they have also stated that a more consistently accurate dose has been achieved. Noble (1966) in a series of laboratory experiments has investigated these faults as well as infection risks.

No infections were recorded in this trial although it is agreed that this could be due to chance since the numbers were small. Sterilization techniques were observed scrupulously and handling of the Dermo-jet was reduced to a minimum. Passive transfer of infection via the nozzle must be considered but, provided scrupulously aseptic techniques are observed, the manifest advantage which the Dermo-jet has over the intradermal needle must surely outweigh the small risks involved.

There exists now, in the literature, a fairly large volume of evidence in favour of the Dermo-jet as an efficient means of giving B.C.G. vaccine. It must also be worth further investigation in military practice as a method of giving other vaccines such as Yellow Fever, Cholera, Measles and perhaps even TABT.

\section{Summary}

B.C.G. vaccine was administered to 263 schoolchildren, 97 by the conventional intradermal method and 166 by the Dermo-jet injector. 
Vaccination by the Dermo-jet compared favourably with the intradermal method and has a marked superiority as regards speed and painlessness.

The disadvantages of the Dermo-jet are described. Mechanical faults and inaccuracy of dose may have been eliminated in recent models of the instrument.

Infection, especially serum hepatitis, may occur but the risks may be small if scrupulously aseptic techniques are used when preparing and operating the Dermo-jet.

\section{REFERENCES}

Bleasdale, H. N. (1965) Tubercle (Lond). 46. 417.

Cooper, C., Morley, D. C., Weeks, M. C., and Beale, A. J. (1966). Lancet, 2.317.

Griffrths, M. J., DavitT, M. C., Brindle, T. W., and Holme, T. (1965). Brit. med. J., 2. 399.

Noble, J., (1966). Pers. Comm.

\section{G.C.M.G.}

\section{Honours and Awards}

Sir Arthur Porritt, Bt., K.C.M.G., K.C.V.O., C.B.E., Governor General and Commander-in-Chief (designate) of New Zealand.

Sir Arthur served in the Army Medical Services and was Consulting Surgeon to 21st Army Group. Currently he is a Member of the Army Medical Advisory Board and Honorary Consultant in Surgery to the Army at Home.

\section{Gallantry in Aden}

From the London Gazette 30th June, 1967 for services in Aden:

\section{M.B.E.}

To be additional member of the Military Division of the most Excellent Order of the British Empire, Captain Jeremy. Stewart COX, R.A.M.C. 